\title{
Land Tenure and Legal Pluralism in the Peace Process
}

\author{
Jon D. Unruh \\ McGill University
}

\begin{abstract}
Land tenure has proven to be one of the most vexing issues in a peace process. The disintegration of land and property rights institutions during armed conflict, and yet the importance of land and property to the conduct of conflict presents particular dilemmas for a peace process attempting to reconfigure aspects of societal relations important to recovery. In this regard understanding what happens to land tenure as a set of social relations during and subsequent to armed conflict is important to the derivation of useful tools for managing tenure issues in a peace process. This article examines the development of multiple, informal 'normative orders' regarding land tenure during armed conflict and how these are brought together in problematic form in a peace process. While there can be significant development of tenurial legal pluralism during armed conflict, it is during a peace process that problems associated with different approaches to land claim, access, use, and disputing become especially acute, because an end to hostilities drives land issues to the fore for large numbers of people over a short time frame.
\end{abstract}

\section{Introduction}

Significant attention is currently being placed on the ability of the peace process to reconstitute important aspects of societal relations necessary for postwar recovery. This occurs as the UN and the international community seek to address the root causes of conflict in a more comprehensive and integrated manner, and follows a general recognition that future instability will often comprise low intensity conflict within nations rather than between them, with their origins buried deep within aggravating problems of inequitable access to resources--including, and often especially, land resources. ${ }^{1}$ While land access or re-access constitute one of the more problematic and volatile facets of societal relations during and subsequent to armed conflict, important operative aspects of land tenure during a peace process remain unexamined, and there exists a lack of theoretical and applied tools to address tenurial issues in the context of postwar social relations. In this regard, one of the most fundamental issues involving property, land, and territorial rights following a war is the fate of land tenure institutions during armed conflict, and how the resulting situation is dealt with in a peace process.

While few civil institutions can endure the stresses of armed conflict, there are, nonetheless, specific institutional needs important to social relations even during times of strife. At the same time, the institutional fluidity of armed conflict allows for opportunities to reconfigure certain institutional arrangements to more closely suit the needs of particular groups and situations. Both can result in the emergence of norms or 
'normative orders', which attempt basic but important institutional services. Land tenure or more specifically tenure security is such an institutional need, especially for largely agricultural societies, due to the relationship between land tenure security and food security. Secure access and control over specific lands can be, or become, important to groups for religious, geographical, economic, or ethnic reasons. Multiple rights to land are common in many areas of the world, and exist in varying degrees of completeness. However this article makes the argument that the confusion, competition, confrontation, and yet importance of seeking secure access to rural lands during and following civil conflict results in a particularly problematic emergence of multiple normative orders for attempting to legitimize land access, claim, and use. The postconflict period can then find conditions of 'legal pluralism' regarding land to be significantly developed, with different sets of normative rules regarding land, property, and territory intricately bound up in the conflict itself. This will especially be the case where land issues are a significant component of the cause and maintenance of the conflict. In this situation, legal pluralism with respect to rights to land that are incompatible, opposed, or in aggregate adds significant confusion and tenure insecurity can jeopardize a peace process.

This article considers the previously unexamined intersection between land tenure, legal pluralism, and the peace process. Subsequent to a review of the role of land tenure in a peace process and a description of legal pluralism, the paper draws on a literature review and the author's experiences (some of which is included in the review) in Somalia, Mozambique, Ethiopia, and Central America, to examine legal pluralism in land tenure which develops during the course of civil conflict and postwar recovery.

\section{Land Tenure in a Peace Process}

The end to armed conflict, especially prolonged civil conflict, creates a situation whereby a significant proportion of the affected population will begin to seek access or re-access to lands and land resources. Given the size of the rural population pursuing this endeavor in many postconflict scenarios, this can be one of the primary features of a postwar phase. The result is that land tenure and property rights issues can be thrust to the fore over large geographic areas in a short period of time for considerable numbers of people. And like the complex histories involving property, land, and territory that play a role in preconflict and conflict scenarios, postwar re-establishment of ownership, use, and access rights will likewise be complicated and problematic, providing significant potential for renewed confrontation ${ }^{2}$.

The importance of land and property rights issues during and subsequent to civil conflict is reflected in the significant role that agrarian reform has $\mathrm{pl}$ ayed in many insurgent and revolutionary agendas. As Shipton ${ }^{3}$ observes, "nothing evokes deeper passions or gives rise to more bloodshed than do disagreements about territory, boundaries, or access to land resources." More broadly, land issues play a fundamental role in postwar reconciliation and economic rehabilitation. Managing such 
issues in an effective manner in a peace process is not only important to avoiding disenfranchisement of local populations from land rights, a primary factor contributing to instability 4 but also to the secure re-engagement of populations in familiar land uses and the resulting agricultural production, food security, and trade opportunities important to recovery.

\section{Tenurial Legal Pluralism and the Peace Process}

\section{Legal Pluralism: Operative Concepts}

The field of legal pluralism has progressed quickly and impressively in recent years, with land tenure playing a significant role in this. ${ }^{5}$ Substantial contributions define legal pluralism in a number of related ways. These range from pluralism in the juristic sense, when a state pursues different bodies of law for different groups of people 6 to asserting that all societies are legally plural in that the process of establishing rules, securing compliance, and punishing rule breakers exists informally in a wide variety of societal subgroups such as families, workgroups, political organizations, and collectives. ${ }^{7}$ Much research and discussion has focused on the latter end of this range, which recognizes legal pluralism as multiple, nonjuristic, alternative, informal forms of 'normative ordering' (e.g., Merry 1988; Griffiths 1986). ${ }^{8}$ Griffiths ${ }^{9}$ notes that the law "which is actually effective on the 'ground floor' of society is the result of enormously complex and usually in practice unpredictable patterns of competition, interaction, negotiation, isolationism, and the like," such that "the legal organization of society is congruent with its social organization." Griffiths ${ }^{10}$ further observes:

Legal pluralism is a concomitant of social pluralism: the legal organization of society is congruent with its social organization. Legal pluralism refers to the normative heterogeneity attendant upon the fact that social action always takes place in a context of multiple, overlapping 'semi-autonomous social fields,' which, it may be added, is in practice a dynamic condition.

Of particular utility here is the semi-autonomous social fields approach initially articulated by Moore11 in which separate social fields of 'legality' with different loci of authority overlap and interact. This interaction over time can take a number of paths from progressive legal reconciliation between fields to increasing separation or multiplication of fields, depending on the nature of the interaction and attendant relevant socio-political, economic, and resource-related forces. Moore ${ }^{12}$ notes the role of semi-autonomous social fields in the way individual and group behavior and the processes of interaction within and between fields determine what 'law' is effectively in place at a given location and moment. Griffiths ${ }^{13}$ contributes to the development of Moore's work, noting that it is to a large degree the network of rights and obligations in human relationships, which constitutes a 'legality' within a social field.

Land tenure, at its most fundamental level, is a system of rights and obligations in human relationships. ${ }^{14}$ Legal pluralism with regard to land tenure signifies the different sets of 
rights and obligations concerning land and property, as these reside within multiple social fields or normative orders. The most pervasive example of legal pluralism regarding land exists in the postcolonial developing world, where, due to the existence of both customary and formal tenurial regimes, legal pluralism in land administration is pursued as an approach to realistic governance. One of the most acute examples of incompatible legal pluralism regarding land resides in the Middle East, where the Israeli-Palestinian lands issue has vexed attempts at peacemaking for some time.

\section{The Problem in a Peace Process}

Land tenure issues can contribute significant risk to a peace process. When incompatibility, competition, and confrontation between different patterns (normative orders) of access, claim, use, disputing, and security regarding land become significantly widespread and severe over the course of a conflict, and/or the aggregate effect of different approaches to land is a significant cause of confusion and tenure insecurity, the result can be profound within the context of a delicate and incipient peace. ${ }^{15}$ Such risks can be especially pronounced when large populations are dislocated during the course of a war, because dislocatees and other marginalized groups often develop or deepen political awareness while dislocated from home areas. As a result, land access problems in a postwar phase can easily be placed within the larger political landscape. ${ }^{16}$ Alexander ${ }^{17}$ examines how such political awareness and mobilization can challenge postwar authority structures and sources of legitimacy--two fundamental aspects of the land and legal pluralism nexus, and two of the most problematic aspects of a peace process.

Especially difficult in periods of recovery are disputes over land between participants in different and, in many cases, opposing tenurial normative orders and the inability of these to connect institutionally in terms of how land disputes are resolved in ways that are viewed as secure and legitimate--and therefore respected. Aggravating such a situation is the greatly diminished capacity of a postwar government to enforce even minor aspects of the pre-existing (preconflict) national tenure system. Because the spatial pattern of tenurial legal pluralism in postwar situations varies significantly, and with it the type, nature, and intensity of forms of pluralism and their interaction, the precise risks to the process are also spatially variable. ${ }^{18}$ Left unattended, the overall property rights arrangement becomes inherently unwieldy with wider repercussions on agricultural recovery, food security, and the political problems associated with ideas about 'home area,' ethnicity, and areas gained or lost by different groups.

\section{The Development of Tenurial Legal Pluralism During Armed Conflict}

\section{Rights and Obligations in Land Tenure}

Armed conflict, especially civil conflicts that are severe and of long duration, profoundly change the relationships among people. This occurs between households, communities, and peoples (ethnic, religious, geographic), and between socioeconomic strata. Because 
of the powerful spatial component of armed conflict, accepted and established rights and obligations regarding land and property can be at the forefront of such change. The sociospatial repercussions of violence, dislocation, destruction of property, battlefield victory and loss, and food insecurity, together with the breakdown of administrative enforcement and other property-related institutions and norms, also significantly alter relationships between people, land uses, production systems, and population patterns. Changes in land tenure during armed conflict are the result of the events and processes in which people's relationships (rights and obligations) to each other change. ${ }^{19}$ In the Middle East conflict, the change in relationships between people over land has manifested itself in a number of ways. One of the more profound changes is among Palestinians themselves--with those caught selling land to Israelis facing a potential death sentence (Greenberg 1997). ${ }^{20}$ In essence, armed conflict and its repercussions reconfigure the network of social relations upon which all land tenure systems depend. The remainder of this section examines four prevailing influences that change rights and obligations in land tenure to result in the development of multiple normative orders regarding land during and subsequent to civil conflict. While there are a number of additional influences that can contribute to this effect, examining all these in their entirety is beyond the scope of this paper. The four influences considered here, changes in population patterns, reduction in state power, identity change, and legitimacy, are nevertheless some of the most pervasive and forcible influences, and serve to illustrate the development of tenurial pluralism in a context of conflict.

\section{Changes in Population Patterns}

Population dislocation due to the effects of armed conflict can play a primary role in the development of legal pluralism with regard to land. Physical separation of people from established home areas and traditions of land use and land tenure, can be the first and most dramatic step toward the development of a changed approach to land rights. This occurs in three stages. First, physical separation changes, terminates, or puts on hold prevailing social rights and obligations among people regarding land and property, especially where actual occupation, or social position forms the basis or a significant aspect of claim. This occurs primarily because community members are not physically present to exercise rights and obligations. In such a situation alternative ways of viewing land can move forward quickly, especially if marginalized groups see an opportunity to enhance rights. The Middle East provides an important variant of dislocation and legal pluralism. Land confiscation and the way it occurs for Israeli settlement-building drives legal and normative rules regarding land into separate fields or domains, as they are applied to and are pursued by the Palestinians, Israelis, and subgroups, with the boundaries of such domains defined in large part by issues inherent in the conflict. ${ }^{21}$

Second, once dislocated, people seek land elsewhere--especially for agricultural populations in pursuit of food security--but with an approach to access, claim, and disputing now different from what prevailed in a home area. This comes about with a change in status as people who were once community members become dislocatees, 
migrants, squatters, female-headed households, and refugees in new locations. Many African populations rely on relatives and other community members for security of person and property and for assistance in disputes. Such a network is an effective rule making and sanction-applying construct. In dislocation due to war however, many variables serve to rework or reconfigure this construct, especially if the new area has little or no community entry. Affected populations (both arriving and receiving) can fairly quickly move to establish alternative land tenure arrangements that follow newly emerging situations and norms, or pursue variations of old arrangements which work under prevailing circumstances. The direction that this emergence takes and how rapidly it occurs can depend to a significant degree on wartime and dislocation experiences.

Third, an ability to return to a predislocation land tenure system in a home area will depend on the length of the war; the degree of intactness of the return community; relationships between those who left and those who stayed; the scale of physical changes at the field, village, and landscape scales as these relate to property rights; and the degree to which individual and community changes during dislocation are still compatible with the previous tenure system. These variables can combine to result in significant resistance and animosity toward returnees by community members who chose not to flee. Such animosity can be especially the case when alternative ideas regarding land tenure are brought back with returnees, particularly when these ideas involve a perceived reduction in rights and/or power for those who stayed. Also relevant to 'going back' are the presence and activities of other actors, including squatters, large landholders, and commercial interests, all of whom may seek access to lands thought to be previously unoccupied or abandoned during the war. Krznaric 22 observes how dislocation influenced the development of legal pluralism over land within groups of Guatemalan returnees versus those who stayed, due to the refugee's raised political awareness during their exile in Mexico. Hammond 23 notes similar contrasts for Nicaragua and E1 Salvador, and Unruh24 describes the changes in evidence for claims to lands in Mozambique that resulted from wartime dislocation.

\section{Reduction in Penetration of State Power}

Civil conflict necessarily results in a reduction in the power and penetration of state law, with the overall effect spatially variable. The repercussions for the state's role in the administration of land and property in this context, and the resulting influences on legal pluralism, are several. Early in a conflict the state's land administration institutions in affected areas of the country can be rendered crippled or inoperable, and rules unenforceable. This comes about due to general insecurity, areas occupied by opposition groups or populations sympathetic to them, diversion of resources, and the destruction of the physical components of the lands system such as local registries and other records. The absence of employees to carry out administrative functions, along with people who previously engaged the state for administrative services, further undermines the functioning of formal property rights institutions. While such effects may be most 
pronounced in areas directly involved in conflict or taken over by opposition groups, or where state enforcement or concern was historically weakest, the federal land and property administration can, over time, experience an overall national reduction in capacity as specific influences become mutually reinforcing: (1) the state's financial resources are diverted to a war effort and elsewhere, (2) administrative personnel become unwilling or unable to travel due to security concerns, (3) significant sectors of the national population begin to question the legitimacy of state institutions, (4) records pertinent to non-affected areas of the country become outdated as land and property transactions take place and go unrecorded during an ongoing conflict, (5) a general recognition emerges of the unworkability of lands and property administration as a national institutional endeavor, and (6) increasing numbers of people abandon the state tenure system in favor of alternatives, which then act to further subtract adherents to state law in a 'momentum effect.'25

In such an environment the derivation of legal pluralism regarding land and property rights can occur: (1) as a need to derive an arrangement that works locally in the absence of functioning state institutions (strictly utilitarian), (2) in the context of a resurgence in the use of certain traditional norms in substate groups (frequently tied to identity), and (3) as areas taken over by the opposition purposefully pursue approaches different from or opposed to the state. ${ }^{26}$

Preconflict ideas of the 'unjustness' in the way the state deals with land rights for portions of the population can constitute an important aggregate force in the reduction of state penetration in land issues during conflict. Such ideas can range from simple disappointment in or distrust of the state and its ability, willingness, or bias in handling land issues, to the perception of the state as the enemy. The latter can be especially powerful if there exists an accumulation of land-related grievances against the state brought on by land alienation and discrimination, corruption, or state intervention in agricultural production, dislocating agricultural and/or population programs, and heavyhanded approaches to enforcement of state decisions and prescriptions regarding land issues. In aggregate, this can result in what Ranger $27(1985,1)$ calls a "historical consciousness of grievances" with regard to land rights issues, which can become especially pronounced if such grievances merge with other issues not necessarily related to land. In such cases plural normative orders, once developed, can persist with considerable tenacity, justifying themselves by appeals to perceived historical wrongs done to certain groups (Merry 1988). ${ }^{28}$

The overall effect of such mistrust or grievance, together with a reduction in state power, is the fairly rapid derivation or resurgence of a variety of alternative forms of land and property rights arrangements during conflict, with the speed and direction of such change dependent on the character of the grievance felt by a particular group and how this intersects with preferred ways of land tenure. After the end of a war, disappointment in the state can manifest itself in different forms of local land administration, particularly 
since the ideology, mobilization, and wartime aspirations of the recent war are still fresh in the minds of many, and a post-conflict state administration can find that it has limited influence. ${ }^{29}$

\section{Identity Change}

For considerable numbers of people who find themselves in conflict scenarios, identity can be, or can become intricately bound up in land occupation, access, or perceived rights to specific lands in very powerful ways. In many cases the existence of ethnic, religious, geographic, or other identities to which primary attachments persist, can be based on connections to land, home area, or territory. ${ }^{30} \mathrm{Smith}^{31}$ notes that if local identity-based groups do not have a relationship with the state that involves attachment and loyalty and ultimately provides for an acceptance of state authority as legitimate, then the state and group identities will be in competition. With armed conflict underway in such a context, some groups will seize upon the opportunity to advance the goals of substate selfdetermination especially with regard to land. With a concurrent reduction in state power, a relative rise in the influence of identity-based attachments to land can occur, especially if there is an identity component to the conflict.

Ibrahim $^{32}$ notes that "the assertion of a person's identity is intended to give meaning to an encounter with others." The definition of identity in a context of armed conflict is often predicated on how an individual or group sees themselves with respect to opposing groups. Thus, approaches to land employed by one group in a conflict can be purposefully rejected by another, leading to a situation of opposed legal pluralism over land. As the identities of those involved in armed conflict develop and take on significant enmity with an opposing group or groups, approaches to land issues will reflect this and can become a prominent feature in the conflict and subsequent peace process. ${ }^{33}$

\section{Legitimacy}

Civil conflict is based on the perception of legitimacy and non-legitimacy in various forms. And because it is legitimacy that is contested during conflict, the emergence or further development of legal pluralism is highly likely, with different normative orders emanating from different loci of what is perceived to be legitimate authority. This is particularly relevant to land, property, and territory, because claims to these are based on notions of legitimacy and authority. ${ }^{34}$

Legitimacy influences the intersection of land tenure and legal pluralism in four primary ways in the context of armed conflict and a subsequent peace process. First, as discussed above, there can be a reduction in the legitimacy of the formal land tenure system for much of the population. While this can be particularly the case for those belonging to or sympathetic to the opposition(s), the reduction in legitimacy for those either neutral or sympathetic to the state is primarily tied to the state's reduced capacity to administer the formal tenure system. ${ }^{35}$ Second, notions of legitimacy regarding claims to land can combine with identity and involve claim justification based on historical occupation 
supported by oral histories that can trace back through time into mythologies about how various peoples came to exist in an area and in the world. ${ }^{36}$ Such justification can gain renewed strength during conflict, and the pursuit of a 'return' to historical lands or territory--from which groups were expelled or departed, recently or long ago--can become a priority in a peace process. In some cases, such a situation can be seen as a singular opportunity to regain historical lands prior to the solidification of peace. Third, forms of land tenure may be created which are directly connected to the opposition or insurgency which is made legitimate by direct military occupation and military strength. ${ }^{37}$ Fourth, legitimacy can follow a reaction to the insecurity generated during conflict and the desire for the return of some form of order in society. The emergence of Shari'a courts in Somalia is one example of this, as is, arguably, the emergence of the Taleban in Afghanistan. Both are able to field their own mechanisms of enforcement for a variety of institutions, including land tenure.

The fate of evidence of rights to land during armed conflict is a particularly relevant manifestation of legitimacy (Unruh 1997). ${ }^{38}$ Claims to properties, lands, and territories have as their defining feature evidence that is regarded as legitimate by members of a certain community. At the same time, people in other and especially opposing communities, can regard such evidence as not legitimate. Often the boundary of a legal field, ${ }^{39}$ with regard to a set of normative rules in such a situation, exists between those who do and do not regard certain forms of evidence as legitimate.

The derivation of evidence plays a role in pluralism. Shipton ${ }^{40}$ notes that within the administration of land, the question of who gets to control the 'language,' and the 'translations' of reality into legitimate evidence (the evidence of human interaction and human-landscape interaction), and how land is dealt with (demarcations, transfers, inheritance, land access, etc.) becomes critically important. ${ }^{41}$ This control over what is or becomes evidence, legitimizes or de-legitimizes units of aggregation, kinds of rights, transactions, rituals, and ways of landuse. ${ }^{42}$ Thus, competition and confrontation over who exercises this control with regard to a specific land area can influence legal pluralism as some claimants find themselves with evidence different from that considered legitimate or possessed by others as war and postwar scenarios develop. ${ }^{43}$ This same effect can manifest itself in a more nuanced fashion as the relative value of pre-existing evidence can shift to reflect changed circumstances. ${ }^{44}$ And in cases of outright victory in a conflict, profound changes in legitimate evidence can occur. ${ }^{45}$

\section{Legal Pluralism and Recovery Scenarios}

The end to a conflict can see legal pluralities regarding land brought together in increased competition and confrontation in a peace process, as the postwar activities and energies of significantly large numbers of people become focused on access to properties and land within a sort time frame. This heightened interaction can result in a more dynamic phase of development for an array of normative orders. As access to land is attempted with considerable urgency during this time, competing claims can result in landholders 
abandoning features of tenure systems because disputes and the lack of legitimate mechanisms to resolve them have made such features unworkable, or they believe there is little point in adhering to tenurial constructs that others are not following. Such a situation then leads individuals and groups to look for alternative ways to access land.

What are the possibilities for managing problematic issues associated with tenurial pluralism during recovery from conflict? The previous section sought to point out how pluralism develops in conflict scenarios. This section examines the management of such legal pluralism in land tenure during a peace process, beginning with the problem of legislative change--the prevailing approach to land issues in a peace process.

\section{The Inadequacy of Legislation Alone}

Legislative change is one of the hallmarks of a peace process. Intended to promote social change, new laws or modifications to laws are meant to aid in the inclusion and reconstruction of society. Revising national policy to incorporate functional aspects of a peace accord involving land and property is frequently an important part of the postwar endeavor. ${ }^{46}$ However, such legislative change can be profoundly out of step with emerging tenure realities in postconflict scenarios. Griffiths ${ }^{47}$ notes that informal ties of mutual rights and obligation are frequently much stronger than formal law, and as such can serve to deflect the latter. Moore ${ }^{48}$ specifically examines the inadequacy of the idea that social change can be brought about by legislation in a context of legal pluralism. The development of Moore's model of the semiautonomous social field in legal pluralism was partially an effort to explain why new, imposed legislation and other legal attempts to direct change did not produce expected results. Thus, Moore ${ }^{49}$ notes:

new laws are thrust upon ongoing social arrangements in which there are complexes of binding obligation already in existence. Legislation is often passed with the intention of altering the ongoing social arrangements in specified ways. [However] [t]he social arrangements are often effectively stronger than the new laws.

This is especially important given that conditions in postconflict situations are such that a recovering state will in many cases be weak and of questionable legitimacy in the eyes of many in civil society. In a peace process sets of rights and obligations that have been created and maintained during a war to facilitate property, land, and territorial needs and aspirations will predate and can be significantly stronger than any new laws attendant on a war-weakened state and fragile peace. This is particularly the case as mechanisms for disseminating and enforcing such laws (especially with agrarian, semi-literate, war-weary populations) will also be weak or nonexistent.

\section{Embracing Multiple Legal Orders in a Peace Process: Forum Shopping}

With a problematic state, and inadequate legislation to resolve important land and property rights dilemmas, the utility of purposefully engaging pluralism in a peace 
process deserves examination. In this context the literature describing 'forum shopping' is significant, and is one of the more valuable applied aspects from the field of legal pluralism. A number of authors note the existence of situations where there are opportunities (especially for litigants) to choose between fora belonging to different normative orders. ${ }^{50}$ And Ostrom et al..$^{51}$ and Ostrom ${ }^{52}$, among others have examined different aspects of negotiation between traditional customary rights and more modern state-based rights. While legal pluralism in land can present significant problems, pluralism can potentially offer certain possibilities with regard to choosing which normative orders and institutions an individual or group believes offers the most advantageous arena in which to pursue important property rights issues. The effect of such forum shopping for land tenure institutions is to create a situation where there can be considerable 'room for maneuver' or negotiability within the political-legal sphere. ${ }^{53}$ This creates the possibility for less violence in a peace process if claimants feel that there are not rigid, uncompromising legal structures of questionable legitimacy confining their options. $^{54}$

The relationship between state law and various normative orders is important with regard to how they together provide a 'menu' for forum shopping in which state law and other normative orders in aggregate constitute "bargaining and regulatory endowments". 55 Such shopping can be connected with local political maneuverings between those whose authority rests with knowledge of and application of laws connected to the state and those whose authority rests with ethnicity, geography, and group experience. ${ }^{56}$

Bavnick ${ }^{57}$ describes a state institutional construct in India whereby local-level state officials are given the discretion to "stand at the interface between the two legal systems [formal and customary] and bear substantial responsibility for adjustments" between systems. This provides an example of some potential utility for a peace process, where specific local-level officials can be charged with facilitating the dialogue, interaction, and adaptation between the state and other normative orders that are in place subsequent to a conflict, especially with regard to land dispute resolution. In Bavnick's example, locallevel officials do not seek to impose state law, but instead attempt to convince, co-opt, or realistically use any legal system or combination thereof to attain the state's objectives.

State recognition of a legally pluralistic land and property situation in a peace process is especially important to a weakened state of questionable legitimacy emerging from civil conflict, as such a state will need the customs and controls within local communities for administration of land. But Griffiths ${ }^{58}$ notes that recognition by the state of legal pluralism adds a "formidable layer" of complexity on the state legal system, with the resulting situation generally regarded as defective and messy. It can be argued, however, that postwar scenarios are already considerably messy, and that the priority should be the peace process. ${ }^{59}$ 


\section{Changes in Postconflict Normative Orders}

Formal recognition of multiple orders with regard to land and property does not mean that such a situation would remain static. Recovery from armed conflict is a time of significant social change. Such change can see forms of legal pluralism evolve significantly during recovery, with such evolution a fundamental aspect of legal pluralism generally. Merry ${ }^{60}$ argues that "any situation of legal pluralism develops over time through the dialectic between legal systems, each of which constitutes and reconstitutes the other in some way." Several studies articulate the progressive expansion or infiltration of state law into non-state normative orders over time, so that in many cases these can come to resemble state law. ${ }^{61}$ And the reverse can also be the case, with state law borrowing concepts and symbols from other normative orders. ${ }^{62}$ Henry ${ }^{63}$ argues that while conflicting normative orders may oppose one another, their proximity allows a "dialectical interaction" in which they are "vulnerable to incremental reformulations."

However, this change in normative orders through interaction is not always slow and incremental. In work relevant to postconflict land tenure situations, Lund ${ }^{64}$ argues that when negotiation is a central feature of land tenure conflicts, "open moments" become important in which intense periods of social rearrangement can occur. An open moment is an opportunity where the room for "situational adjustment is great and hence where the capacity to exploit it is crucial for the actors". In war and postwar situations, legitimacy, authority, and rules are much more fluid and open than perhaps at any other time. Thus an important feature in postwar situations is the rapidity with which social relationships change to reflect the rapid change in society. Open moments are thus very likely to occur in peace process situations when much about land tenure, legitimacy, rules, and authority are being challenged by the forces associated with recovery.

Griffiths ${ }^{65}$ notes the existence of the direction of a path of interaction in legal pluralism toward eventual unification with state law, which acts to put pressure on social reality toward this eventual goal. Griffiths thus observes the relationship between legal pluralism and nation building as one in which legal pluralism is something that is often allowed to recalcitrant parts of society on the path toward and in the process of nation building.

The importance of negotiability between normative orders (including formal orders) has recently resulted in a paradigm shift more generally for African land tenure, and how states and development efforts have dealt with tenure. Bruce and Migot-Adholla ${ }^{66}$, in editing a volume concerning this shift, observe that given the history of problems associated with attempting to simply replace customary tenure with formal state tenure systems, there must now be movement away from the 'replacement paradigm' in land tenure for nation building and development efforts generally, toward an 'adaptation paradigm' in which state and non-state tenure systems are encouraged to adapt to each other over time. Bruce ${ }^{67}$ argues that such an approach needs a legal and administrative arrangement that supports the evolutionary change in customary tenure rules, and implies a clear recognition of the legal standing (applicability and enforceability) of customary 
tenure rules. Bruce et al. ${ }^{68}$ note in the same volume the centrality of conflict resolution in the negotiation and evolution of land tenure systems as they interact.

$[\mathrm{r}]$ ather than rewrite the laws governing property rights--an effort which will serve mainly to introduce another set of arguments into ongoing debates over access to land--governments should focus on strengthening institutions for the mediation of what, in changing and unstable economies, will continue to be conflicting interests of farmers and others with respect to rights in rural land.

In a more structured sense Bruce et al. ${ }^{69}$ point out that there is a need to look at "how and on what terms [legal] recognition of indigenous land tenure rules is most effective, and how dispute settlement mechanisms can best be framed to facilitate the process of legal evolution." Such an evolutionary or adaptation approach to tenurial legal pluralism in a peace process is one way to operationalize the need to address complicated pluralistic land issues subsequent to armed conflict.

The onset of peace can find many rural resource users seeking to claim or re-claim rights to land with new urgency. The wartime emergence of legal pluralism then acts to increase competition over land and between jurisdictions belonging to different normative orders. With conventional top-down approaches for a peace process proving ineffective for many of today's conflicts, there is increasing recognition that customary and local ways of interaction in such areas as access to and use of resources, need to be identified within the socio-cultural and agro-ecologic contexts of countries prone to and recovering from war, and be incorporated into conventional approaches to peacemaking. ${ }^{70}$ There are indications that if such customary features are identified, recognized, and supported as assets in the larger setting of the peace process they can become powerful deterrents to the escalation or re-escalation of conflicts. ${ }^{71}$ 


\section{Endnotes}

1 See for example B. Crossette,. "Leaders Envision Broad New Role For UN Council: Peacekeeping At Issue - Top Officials Attending Session Discuss Causes Of Conflict In Poorest Nations." New York Times, Sept. 8 (2000); United Nations Development Programme (UNDP) "Human Development Report, Mozambique." United Nations Development Programme. (1994); M. van Creveld, The Transformation of War (New York: The Free Press. 1991); T.F. Homer-Dixon, Environmental change and violent conflict. Occasional Paper No 4. International Security Studies Program, Cambridge MA, USA: American Academy of Arts and Sciences, (1990); R. D. Oakley, "A diplomatic perspective on African conflict resolution". In African Conflict Resolution: The US Role in Peacemaking, eds. D. R.. Smock, and C.A. Crocker (Washington D.C: US Institute of Peace Press, 1995); C.A. Crocker, "What kind of role in African conflict resolution?" in African Conflict Resolution: The US Role in Peacemaking, eds. D. R.. Smock, and C.A. Crocker (Washington D.C: US Institute of Peace Press, 1995); C. Hume, Ending Mozambique's War: The Role of Mediation and Good Offices (Washington D.C: United States Institute of Peace Press, 1994); M. Sahnoun, "Managing conflict after the cold war," Horn of Africa Bulletin 8 (1996):1, 35

2 A. Vines, RENAMO: From Terrorism to Democracy in Mozambique? (London: Center for Southern African Studies and University of York, James Currey, 1996); V. Percival, and T. Homer-Dixon, "Environmental scarcity and violent conflict: the case of South Africa," (Toronto: Project on Environment, Population, and Security, University of Toronto, 1995); C. Crocker, and F.O. Hampson, "Making peace settlements work". Foreign Policy 104 (1996): 54-71;

${ }^{3}$ P. Shipton, "Land and culture in tropical Africa: soils, symbols, and the metaphysics of the mundane," Annual Review of Anthropology 23 (1994): 347-377.

${ }^{4}$ R.A. Hutchinson, Fighting for Survival: Insecurity, People and the Environment on the Horn of Africa. (Gland, Switzerland: International Union for the Conservation of Nature IUCN, 1994).

${ }^{5} \mathrm{~F}$, von Benda-Beckmann, "Anthropological approaches to property law and economics," European Journal of Law and Economics 2 (1995): 309-336; M. Galanter, "Justice in many rooms: courts, private ordering and indigenous law," Journal of Legal Pluralism 19 (1981): 1-47; S.E. Merry, "Legal pluralism," Law and Society Review 22 (1988):

869-896; S. Moore, "Law and social change: the semi-autonomous social field as an appropriate field of study," Law and Society Review 7 (1973): 719; J. Griffiths, "What is legal pluralism?" Journal of Legal Pluralism 24 (1986): 1-52. 
${ }^{6}$ Merry, "Legal pluralism."

7 R.L. Abel, The Politics of Informal Justice, 2 Vols. (New York: Academic Press, 1982); S. Henry, "Community justice, capitalist society and human agency: the dialectics of collective law in the cooperative," Law and Society Review 19 (1985): 303.

8 Merry, "Legal pluralism;" Griffiths, "What is legal pluralism?"

${ }_{9}$ Griffiths, "What is legal pluralism?" 39.

${ }^{10}$ Griffiths, "What is legal pluralism?" 38.

${ }^{11}$ Moore, "Law and social change: the semi-autonomous social field as an appropriate field of study,"

${ }^{12}$ Moore, "Law and social change: the semi-autonomous social field as an appropriate field of study,"

${ }^{13}$ Griffiths, "What is legal pluralism?"

${ }^{14}$ S.E. Migot-Adholla, and J.W. Bruce, "Introduction: are indigenous African tenure systems secure?" in Searching for Land Tenure Security in Africa, eds. J.W. Bruce and S.E. Migot-Adholla (Dubuque Iowa: Kendall/Hunt Publishing, 1994).

${ }_{15}$ The land issue in the peace accord for El Salvador was vague, contributing to different expectations, which in turn led to serious stumbling blocks in the implementation of the land question. The land issue ultimately became the final sticking point in the peace process, serving to block complete demobilization. In Nicaragua, the contras re-armed during the peace process over misunderstandings regarding the issue of land access. See A. de Soto, and G. del Castillo, "Implementation of comprehensive peace agreements: staying the course in El Salvador," Global Governance 1 (1995): 189-203. Subsequent to the end of the Mozambican RENAMO war, the author was employed as a technical assistant to the national land policy reform effort, and observed formidable land tenure problems in the Mozambican interior that significantly aggravated the ongoing peace process. 
${ }_{16}$ R. Ek, and A. Karadawi, "Implications of refugee flows on political stability in the Sudan," Ambio 20 (1991): 196-203; T. Basok, "The troubled road to repatriation in Central America: lessons learned by refugees in exile," Refuge 13 (1994) : 11-12; J. Alexander, "Things fall apart, the center can hold: processes of post-war political change in Zimbabwe's rural areas." in Zimbabwe's Liberation War, eds. T. Ranger and N. Bhehe (London: James Currey, 1992); R. Krznaric, "Guatemalan returnees and the dilemma of political mobilization,” Journal of Refugee Studies 10 (1997) : 61-78.

${ }^{17}$ Alexander, "Things fall apart, the center can hold: processes of post-war political change in Zimbabwe's rural areas.”

18 J. Unruh, "Land tenure and identity change in postwar Mozambique" GeoJournal 46 (1998): 89-99; illustrates how a combination of factors in postwar Mozambique led to concentrations of migrants, large holders, and established customary groups in agronomically valuable areas, all pursuing very different approaches to land access, claim, and use. Significant incompatibilities in these pursuits created problems for the peace process in these areas. As civil conflict grew in Somalia, certain areas of the country were being claimed by nomadic pastoralists under clan transient-access rights arrangements, by small-scale agriculturalists using historical customary rights of occupation, by large scale-land interests accessing lands through the instruments of the state, as well as by heavily armed interests seeking access and control over lands by force; see

J.D. Unruh, "Resource Sharing: small holders and pastoralists in Shalambood, Lower Shabelle Region," in The Struggle for Land in Southern Somalia: The War Behind the War. eds, C. Besteman, and L. Cassanelli (Boulder CO: Westview Press, 1996).

${ }^{19}$ Fundamental to the idea of legal pluralism itself is the notion of group membership, with shared experience operating significantly in how membership operates. From work in Mozambique and Somalia the author has observed that shared group experience in a context of armed conflict can drive group re-definition. Often important aspects of preconflict group definition can be reduced in importance as other more immediate aspects concerned with survival are given priority during and immediately after a war. Thus combatants, dislocatees, migrants, entrepreneurs, refugees, ethnic groups, elites, and those connected with the state and various opposition groups all find themselves in a 'position' with regard to the conflict and how they manage near-term constraints and opportunities. 
20 J. Greenberg, "Gaza Arabs and Israelis clash in land dispute," New York Times, 1997, June 13.

${ }^{21}$ S.E. Cohen, "The Politics of Planting: Israeli-Palestinian Competition for Control of Land in the Jerusalem Periphery," Geography Research Paper No. 236, Chicago: University of Chicago Press. 1993

${ }^{22}$ Krznaric, "Guatemalan returnees and the dilemma of political mobilization," Observes in Guatemala, such awareness raising, itself different for different groups of dislocatees, was the result of the opportunity to advance certain interests suppressed under the predislocation political arrangement--such as those of women, lower socioeconomic strata, and other marginalized groups. An organizational capacity also emerged within some sectors of the refugee returnee community that adhered to a transnational language of rights (human rights, refugee rights) that was appropriated and used by groups of returnees.

${ }^{23}$ J. Hammond, "War up-rooting and the political mobilization of Central American refugees," Journal of Refugee Studies 6 (1993): 104-122.

${ }^{24}$ J.D. Unruh, "Post-conflict recovery of African agriculture: critical resource tenure in Mozambique," Ph.D. Dissertation, University of Arizona (1997); also For Mozambique, because land rights for the customary tenure system were bound in historical interconnections of community interaction regarding land, and locally legitimate evidence of rights, dislocation resulted in a shift of legitimate evidence for many dislocated groups (emergence of alternative norms) in two ways. First, changes in physical evidence and community interaction regarding this evidence meant that shifts in the availability and legitimacy of evidence occurred; and second, re-accessing home areas meant dealing with squatters and large commercial cotton interests that occupied such areas during the war and held very different evidence of land access and occupation to be legitimate.

25 These processes were observed by the author over a period covering a total of three years while working on land tenure projects in Somalia and Mozambique. 
26 In Somalia, the complete reduction of state power and the search for order led to the installation of Islamic Shari'a courts for administration and enforcement of a number of aspects of society, including land and property rights and land tenure dispute resolution. See United Nations Development Programme - Emergencies Unit for Ethiopia (UNDPEUE), "Somalia: power of Islamic courts and Shari'a militia increasing," Horn of Africa the Monthly Review, Addis Ababa, Ethiopia: UNDP-EUE (1999). During Mozambique's RENAMO war, the considerable reduction in the capacity of the state to administer land allowed not only the RENAMO opposition, but also a variety of groups to exert alternative approaches to land access and use. Several commercial interests with international backing also derived approaches to land tenure by obtaining official land documents from the government, then making arrangements with the RENAMO opposition regarding access to tracts of land and providing their own paramilitary enforcement of this access, which included taking over land occupied by customary groups. At the same time, many communities in Mozambique who were not dislocated refocused their attention on their own traditional ways of land access, dropping any recognition of state land administration that existed prior to the war. In some cases this allowed the occupation, or re-occupation, of lands formerly seized by the state or commercial interests.

27 T. Ranger, Peasant Consciousness and Guerrilla War in Zimbabwe (London: James Currey, 1985:1); also notes that land grievances had been at the core of Salvadoran friction since the colonial era, and were some of the primary causes of the conflict in the 1980s. This was also the case in Zimbabwe's liberation war regarding land expropriations by the Rhodesian state. See Ranger, Peasant Consciousness and Guerrilla War in Zimbabwe. And in the author's experience both Mozambique's RENAMO war and Ethiopia's Derg war significant grievances surfaced as a result of government villagization programs. Variants of such conditions also prevail for recent wars in Central America and problems in southern Mexico, and in the way the land issue has been handled over the course of the conflict between the Palestinians and the Israelis. See Cohen "The Politics of Planting: Israeli-Palestinian Competition for Control of Land in the Jerusalem Periphery;" and Greenberg, "Gaza Arabs and Israelis clash in land dispute." In the latter example, land confiscation and the way it occurs for Israeli settlement-building has been a significant feature of the overall problem. This has also been a fundamental part of the situation in Somalia, where disputes over resource access such as grazing and water resources quickly merged with a history of perceived wrongs done to clans and subclans on issues not necessarily related to land. Animosities tied to historical events also have played a fundamental role in the Balkans and Middle East conflicts, see R.C. Holbrooke, To End a War (New York: Random House, 1998); and Cohen, "The Politics of Planting: Israeli-Palestinian Competition for Control of Land in the Jerusalem Periphery." 
${ }^{28}$ Merry, "Legal pluralism;" Griffiths, "What is legal pluralism?"

${ }^{29}$ Subsequent to the liberation war in Zimbabwe, Alexander, "Things fall apart, the center can hold: processes of post-war political change in Zimbabwe's rural areas." notes that a reaction against the state regarding land and property occurred at the grassroots level. Local distrust of the state was manifest even when the insurgency won and went about establishing a government and policies regarding land, because local chiefs were purposefully left out of a reconstituting state due to their alliance with the Rhodesian administration. Aexander "Things fall apart, the center can hold: processes of post-war political change in Zimbabwe's rural areas" p. 14, also observes that "the modernizing agenda and authoritarian practices of the [postwar] development bureaucracies helped to create a disaffected constituency upon which the traditional leaders were able to draw."

${ }^{30}$ Unruh, "Land tenure and identity change in postwar Mozambique."

${ }^{31}$ A.D. Smith, "Toward a geography of peace in Africa: re-defining substate determination rights," in Nationalism, Self Determination and Political Geography. eds. R.J. Johnston, D.B. Knight, and E. Kofman (New York: Croom Helm, 1988)

32 F. Ibrahim, "Editorial: identities in sub-Saharan Africa." GeoJournal 46 (1998):77-78.

${ }^{33}$ Cohen "The Politics of Planting: Israeli-Palestinian Competition for Control of Land in the Jerusalem Periphery," describes the difference between Palestinian and Israeli approaches to land and land tenure, and the ways in which these are grounded in identity. Identity for Palestinians has developed, to a significant degree, to mean opposition to Israel, Israelis, and Israel's approach to land administration, especially the construction of settlements. Smith, "Toward a geography of peace in Africa: re-defining substate determination rights," notes that ethnic identities are fundamentally tied to territory in Africa. As a result, identity in land is a primary source of legal pluralism with regard to land tenure in Africa. In Mozambique, because local rivalries between communities were caught up in the war, the result in some areas was a checkerboard effect of community-level alliances with RENAMO and FRELIMO with proximate communities' electing to side with the opposite of their neighbors. See J. Hanlon, Mozambique: Who Calls the Shots? (London: James Currey, 1991). The two sides in Mozambique's war employed quite different approaches to local communities and land administration, which in several ways were purposefully different from the opposition. 
${ }^{34}$ The importance of legitimacy in conflict (including armed conflict explicitly over land) is noted specifically in studies on Chiapas, the Gaza Strip, and South Africa and generally in civil conflicts; see respectively, P. Howard, and T. Homer-Dixon. Environmental scarcity and violent conflict: the case of Chiapas, Mexico (Toronto: Project on Environment, Population, and Security, University of Toronto, 1995); K. Kelly, and T. Homer-Dixon, Environmental scarcity and violent conflict: the case of Gaza (Toronto: Project on Environment, Population, and Security, University of Toronto, 1995); V. Percival, and T. Homer-Dixon. Environmental scarcity and violent conflict: the case of South Africa. (Toronto: Project on Environment, Population, and Security, University of Toronto, 1995); T.F. Homer-Dixon, "Environmental change and violent conflict" Occasional Paper No 4. International Security Studies Program, Cambridge MA, USA: American Academy of Arts and Sciences, 1990. And Latin America also has provided many vivid examples of the link between legitimacy and significantly different approaches to land.

${ }^{35}$ Unruh, "Post-conflict recovery of African agriculture: critical resource tenure in Mozambique."

36 J. Comaroff, and R. Simon. "The invocation of norms in dispute settlement." in Social Anthropology and Law. eds. Hamnet, I. (London: Academic Press, 1977; Unruh, "Postconflict recovery of African agriculture: critical resource tenure in Mozambique." 
37 Mozambique again provides an example where RENAMO, during the war and the subsequent peace process, both reallocated land as a way to gain support and turned away those who had been issued land concessions by the FRELIMO government, regarding these as illegitimate. See Hanlon, Mozambique: Who Calls the Shots? At the same time, RENAMO allocated and reallocated land to smallholders for the purpose of near-term food supply and issued its own concessions for timber and other resource extraction activities likewise regarded as not legitimate by the FRELIMO government See Vines, RENAMO: From Terrorism to Democracy in Mozambique? And Unruh, "Post-conflict recovery of African agriculture: critical resource tenure in Mozambique." During the war and immediately after, some international agribusiness interests, in a clear recognition of the legally pluralistic situation, simultaneously engaged FRELIMO and RENAMO land access arrangements for the purpose of large-scale cotton operations. Such an endeavor then had further pluralistic repercussions regarding land in that those adhering to customary tenure systems in these areas were forcibly relieved of land while dislocatees from elsewhere serving as laborers were given their own land to farm in order to feed themselves. See Unruh, "Post-conflict recovery of African agriculture: critical resource tenure in Mozambique." And Alexander, "Things fall apart, the center can hold: processes of post-war political change in Zimbabwe's rural areas," charts explicitly the process of the formation of legal pluralism regarding land during Zimbabwe's liberation war. In this case, the insurgents provided guaranteed land access, an end to land taxation, and political and economic autonomy.

38 Unruh, "Post-conflict recovery of African agriculture: critical resource tenure in Mozambique."

39 Griffiths, "What is legal pluralism?"

40 Shipton, "Land and culture in tropical Africa: soils, symbols, and the metaphysics of the mundane,"

41 A.B. Murphy, "Historical justifications for territorial claims." Annals of the Association of American Geographers 80 (1990): 531-548.

42 Shipton, "Land and culture in tropical Africa: soils, symbols, and the metaphysics of the mundane," 
${ }^{43}$ The decision by the international community to allow the Bosnian Serbs to keep lands seized from Bosnia and Herzegovina in a campaign of 'ethnic cleansing' meant that virtually no evidence other than ethnicity was legitimate subsequent to the conflict, see E. Sciolino, "U.S. backs Bosnian peace plan; Serbs may keep occupied land," New York Times, 1993, February 11, p. A1. Thus property holders who were 'cleansed' from certain areas were no longer able to use what were once legitimate titles or other documents as evidence for occupation of property. See Holbrooke, To End a War. For Somali pastoralists attempting to access traditional watering points and grazing lands during that conflict, frequently traditional customary evidence such as membership in a specific clan or subclan, testimony by fellow pastoralists, direct occupation and history of land use were regarded as no longer legitimate evidence for rights of access and use, as evidence of a relationship with specific militias gained in value.

44 This was the case in Mozambique, where 'social' customary evidence such as testimony, community and lineage membership, and history of occupation were significantly devalued due to widespread dislocation. At the same time, the existence of permanent, physical investments in land, such as agroforestry trees, greatly increased in value as evidence. See Unruh, "Post-conflict recovery of African agriculture: critical resource tenure in Mozambique."

${ }^{45}$ From work in Ethiopia in 1999, the author has found that such was the fate of many land documents in Ethiopia when the Derg military regime took power in the mid 1970s, and again 16 years later when the Tigrayan-Eritrean forces took over.

46 For example see The World Bank and The Carter Center (WBCC) From Civil War to Civil Society: The Transition from War to Peace in Guatemala and Liberia. (Atlanta: The World Bank and The Carter Center, 1997); African-European Institute. Acordo Geral de Paz de Mocambique (Amsterdam: African-European Institute, 1993); N. J. Colletta, M. Kostner, and I. Wiederhofer, The transition from war to peace in sub-Saharan Africa (Washington DC: The World Bank, 1996).

47 Griffiths, "What is legal pluralism?"

48 Moore, "Law and social change: the semi-autonomous social field as an appropriate field of study,"

49 Moore, "Law and social change: the semi-autonomous social field as an appropriate field of study," p.719 
${ }^{50} \mathrm{M}$. Bavnick,. "A matter of maintaining peace, state accommodation to subordinate legal systems: the case of fisheries along the Coromandel coast of Tamil Nadu, India," Journal of Legal Pluralism 40 (1998):151-170; Galanter, "Justice in many rooms: courts, private ordering and indigenous law;" Benda-Beckmann, "Anthropological approaches to property law and economics;" R.L. Abel,. "A comparative theory of dispute institutions in society," Law Society Review 8 (1973): 217-347

${ }^{51}$ E. Ostrom, T. Dietz, N. Dolsak, P.C. Stern, S. Stonich, E.U. Weber (eds.) The Drama of the Commons (Washington DC, National Academy Press, 2001).

52 E. Ostrom, Governing the Commons: The Evolution of Institutions for Collective Action (Cambridge, UK, Cambridge University Press, 1990)

${ }_{53}$ M. Lund, Preventive Diplomacy: a Strategy for Preventing Violent Conflicts. (Washington DC: US Institute of Peace Press, 1996)

${ }^{54}$ S. Berry, No Condition is Permanent: The Social Dynamics of Agrarian Change in SubSaharan Africa. (Madison USA: University of Wisconsin Press, 1993) argues that such negotiability of relationships and associated rules is a fundamental characteristic of almost all African societies, with Lund, Preventive Diplomacy: a Strategy for Preventing Violent Conflicts, arguing that such negotiation actually is indicative of all societies. Galanter, "Justice in many rooms: courts, private ordering and indigenous law;" notes that within several indigenous groups disputants shop for applicable fora from any sector--local, traditional, state, etc.--to use for their own local political agendas.

${ }^{55} \mathrm{~F}$. von Benda-Beckman, "Some comments on the problems of comparing the relationship between traditional and state systems of administration of justice in Africa and Indonesia," Journal of Legal Pluralism 19 (1981): 117 
56 This is especially the case in countries with a recent history of colonialism, where the state legal system is almost always a version of the colonial order with a European conceptual foundation. See S. Moore, "Law and social change: the semi-autonomous social field as an appropriate field of study" Law and Society Review 7 (1973): 719. Such an order can have less in common with other legal orders indigenous to the country than in western countries where non-state legal systems "blend more easily into the landscape," see Merry, "Legal pluralism.” p. 880. In such a situation, the social distance between the state and non-state legal orders will be significant, and, as a result, addressing the relationship between the two in a peace process becomes more important, as the underlying conceptual foundations do not combine easily with one another. Also see M.B. Hoocker, Legal Pluralism: An Introduction to Colonial and Neo-Colonial Law. (Oxford: Claredon press, 1975).

57Bavnick,. "A matter of maintaining peace, state accommodation to subordinate legal systems: the case of fisheries along the Coromandel coast of Tamil Nadu, India," p. 166

58 Griffiths, "What is legal pluralism?"

59 In this regard Ethiopia will be an interesting place to watch. After several decades of civil conflict, significant legal pluralism exists and has been formally recognized in a number of important domains. Ethiopia's constitutional article 78 (5) accords full recognition to customary and religious courts of law and their legal guarantee is ensured. In Ethiopia significant room appears to be allowed for litigants to 'forum shop' because such customary and religious courts only hear cases where both contesting parties consent to the forum. See United Nations Country Team for Ethiopia (UNCTE) "Situation Report for Ethiopia - September - October 1999," (Office of the UN Resident Coordinator, Addis Ababa, Ethiopia, 1999). In El Salvador's Chapultapec peace agreement, as in the Mozambican peace accord and subsequent legislation regarding land, state recognition of pluralism have contributed much to the success of the peace processes in these two countries, particularly considering the large role that land issues have played in these conflicts. In both cases such recognition was a primary vehicle to facilitate the re-integration of much of the population into productive activities. See for El Salvador and Mozambique, respectively de Soto, and del Castillo, "Implementation of comprehensive peace agreements: staying the course in El Salvador;" and Unruh, "Postconflict recovery of African agriculture: critical resource tenure in Mozambique."

${ }^{60}$ Merry, "Legal pluralism," p. 884. 
${ }^{61} \mathrm{~J} . \mathrm{S}$. Auerbach, Justice Without Law? (Oxford: Oxford University Press, 1983); H.W. Arthurs, Without the Law: Administrative Justice and Legal Pluralism in Mid 19th Century England. (Toronto: University of Toronto Press, 1985); L. Nader, "The recurrent dialectic between legality and its alternatives," University of Pennsylvania Law Review 132: 621, 1984); C. Harrington, Shadow Justice: the Ideology and Institutionalization of Alternatives to Court (Westport CO, USA: Greenwood Press, 1985).

62 G. Silliman, "A political analysis of the Philippines' Katarungang Pambarangay system of informal justice through mediation," Law and Society Review 19 (1985): 279; R.M. Hayden, "A note on Caste Panchayats and Government courts in India: different kinds of stages for different kinds of performances.” Journal of Legal Pluralism 22 (1984): 43.

${ }^{63}$ Henry, "Community justice, capitalist society and human agency: the dialectics of collective law in the cooperative," p. 303

${ }^{64}$ Lund, Preventive Diplomacy: a Strategy for Preventing Violent Conflicts, p. 5

${ }^{65}$ Griffiths, "What is legal pluralism?"

66 J.W. Bruce, and S.E. Migot SE (eds.) Searching for Land Tenure Security in Africa (Dubuque, USA: Kendall/Hunt Publishing Co. 1994)

${ }^{67}$ Bruce and Migot, Searching for Land Tenure Security in Africa.

68 J. W. Bruce, S.E. Migot-Adholla, and J. Atherton. "The findings and their implications: institutional adaptation or replacement?" in Searching for Land Tenure Security in Africa. eds. J.W. Bruce, and S.E. Migot- Adholla (Kendall/Hunt Publishing, Dubuque Iowa, 1994, p. 62). See also Moore, "Law and social change: the semi-autonomous social field as an appropriate field of study;" and L.L. Rose, The Politics of Harmony: Land Dispute Strategies in Swaziland. (Cambridge UK, Cambridge University Press 1993).

69 Bruce et al. "The findings and their implications: institutional adaptation or replacement?" p. 262; And as Bruce et al., mention, in situations where some land users are given registered title and others are not, clear recognition of customary rights together with a highly participatory adjudication process is thought to provide the best safeguard against extinction of land rights for those without title. 
${ }^{70}$ Cohen, "The Politics of Planting: Israeli-Palestinian Competition for Control of Land in the Jerusalem Periphery;" Horn of Africa Bulletin (HAB) "EU plans crisis prevention in Africa." Horn of Africa Bulletin 8 (1996) 2; S. Willett, "Ostriches, wise old elephants and economic reconstruction in Mozambique." International Peacekeeping 2 (1995): 34-55.

71 J. Chopra, "The peace maintenance response." Security Dialogue 28 (1997): 177-189; J.D. Unruh, "Post-conflict recovery of African agriculture: The role of 'critical resource' tenure." Ambio 24 (1995): 343-350; Homer-Dixon, "Environmental change and violent conflict;" Lund, Preventive Diplomacy: a Strategy for Preventing Violent Conflicts; D.R. Smock, (ed.) Making War and Waging Peace: Foreign Intervention in Africa.

(Washington DC: US Institute of Peace Press, 1993). 